\title{
Modeling the Impact of Fertilizers on Groundwater Quality in Hormat-Golina Sub-basin, Golina-Basin, Ethiopia
}

\author{
Mengesha Tesfaw ${ }^{1, *}$, Tewodros Assefa Nigussie ${ }^{2}$ \\ ${ }^{1}$ Department of Water Resource and Irrigation Engineering, Woldia University, Woldia, Ethiopia \\ ${ }^{2}$ Department of Water Resource and Irrigation Engineering, Hawassa University, Institute of Technology, Hawassa, Ethiopia
}

Email address:

mengesha816@gmail.com (M. Tesfaw), hiyawtewodros@gmail.com (T. A. Nigussie)

*Corresponding author

\section{To cite this article:}

Mengesha Tesfaw, Tewodros Assefa Nigussie. Modeling the Impact of Fertilizers on Groundwater Quality in Hormat-Golina Sub-basin, Golina-Basin, Ethiopia. Journal of Water Resources and Ocean Science. Vol. 10, No. 3, 2021, pp. 46-52. doi: 10.11648/j.wros.20211003.12

Received: March 3, 2021; Accepted: May 11, 2021; Published: June 3, 2021

\begin{abstract}
Groundwater, in many parts of the world, is under risk as a result of excessive withdrawal, mismanagement and contamination. A number of studies have been carried out in this respect, but most of them have not predicted groundwater quality concerning anthropogenic stress. As opposed to this, in this study, groundwater fluctuation with respect to human pressure was investigated in Hormat-Golina Sub-basin of the Golina-Basin of Ethiopia. Visual MODFLOW Flex 5.1 model was used to simulate groundwater flow in response to different stress periods in the study area. The study showed that the initial concentration values were measured in each nutrient chemical species. The impacts of climate change and human pressure on groundwater have been the greatest threats in those supply wells. Decreased in pumping rate with increased recharge rate has accomplished to restore and protect the groundwater resources which is the best option for groundwater restoration and monitoring. Anthropogenic pressures including the application of fertilizers were a considerable cause of degraded groundwater quality in relation to Nitrate and Phosphate concentration with series of time. The groundwater quality has deteriorating with the applied Urea and DAP fertilizes in the selected wells of Hormat-Golina Sub-basin. Farmers have encouraged using practices that minimize the risk of groundwater pollution by carefully controlling and timing of the use of fertilizers to avoid over application.
\end{abstract}

Keywords: Human Pressure, Groundwater Quality, Hormat-Golina, Ethiopia

\section{Introduction}

Groundwater, in many parts of the world, is under risk because of excessive extraction, mismanagement and contamination as a result of anthropogenic factors in addition to natural causes such as climate change $[2,4-7]$. The release and migration of pollutants from surface sources (in particular, cultivation and application of chemical fertilizers) and on-farm activities in rural areas can affect groundwater quality in the supply wells [8-10].

Groundwater modeling is a tool which is used for water resources planning and management, groundwater protection and giving recommended remedial action by considering the output of the model [3].

In Ethiopia there are a number of irrigation projects, among which Raya Kobo Irrigation Project is one that mainly depends on the groundwater source. The anthropogenic pressures including, application of fertilizers can cause a pollution of groundwater sources and the progressive deterioration of groundwater quality in relation to Nitrate and Phosphate concentration.

All previous studies had not been explored the predicted groundwater flow dynamics concerning to anthropogenic stress, but this study has developed on the groundwater quality fluctuation with respect to human pressure.

In this Sub-basin since the establishment of the project, scientific studies had not been conducted in related to the effect of chemical fertilizers on groundwater quality.

Hence, the present study has initiated to quantify the groundwater head and its respected drawdown level in before and after irrigation season. 


\section{Material and Methods}

\subsection{Description of the Study Area}

This study has carried out in the Hormat-Golina Sub-basin of Kobo Girana Irrigation Project. This Sub-basin is found in Kobo District in Golina-Basin. The attitude of Hormat-
Golina Sub-basin ranges $\mathrm{g}$ from $1400 \mathrm{~m}$ to $3100 \mathrm{~m}$ above sea level and the Sub-basin is located between $39^{\circ} 14^{\prime} 0^{\prime \prime}$ to $39^{0} 45^{\prime} 0^{\prime \prime}$ E Longitudinal and $12^{0} 2^{\prime} 0^{\prime \prime}$ to $12^{0} 20^{\prime} 0^{\prime \prime} \mathrm{N}$ Latitude geographical coordinate system (Figure 1). The area of the Sub-basin is $234 \mathrm{~km}^{2}$. The upper boundary of Hormat-Golina Sub-basin is the groundwater divide line [11].

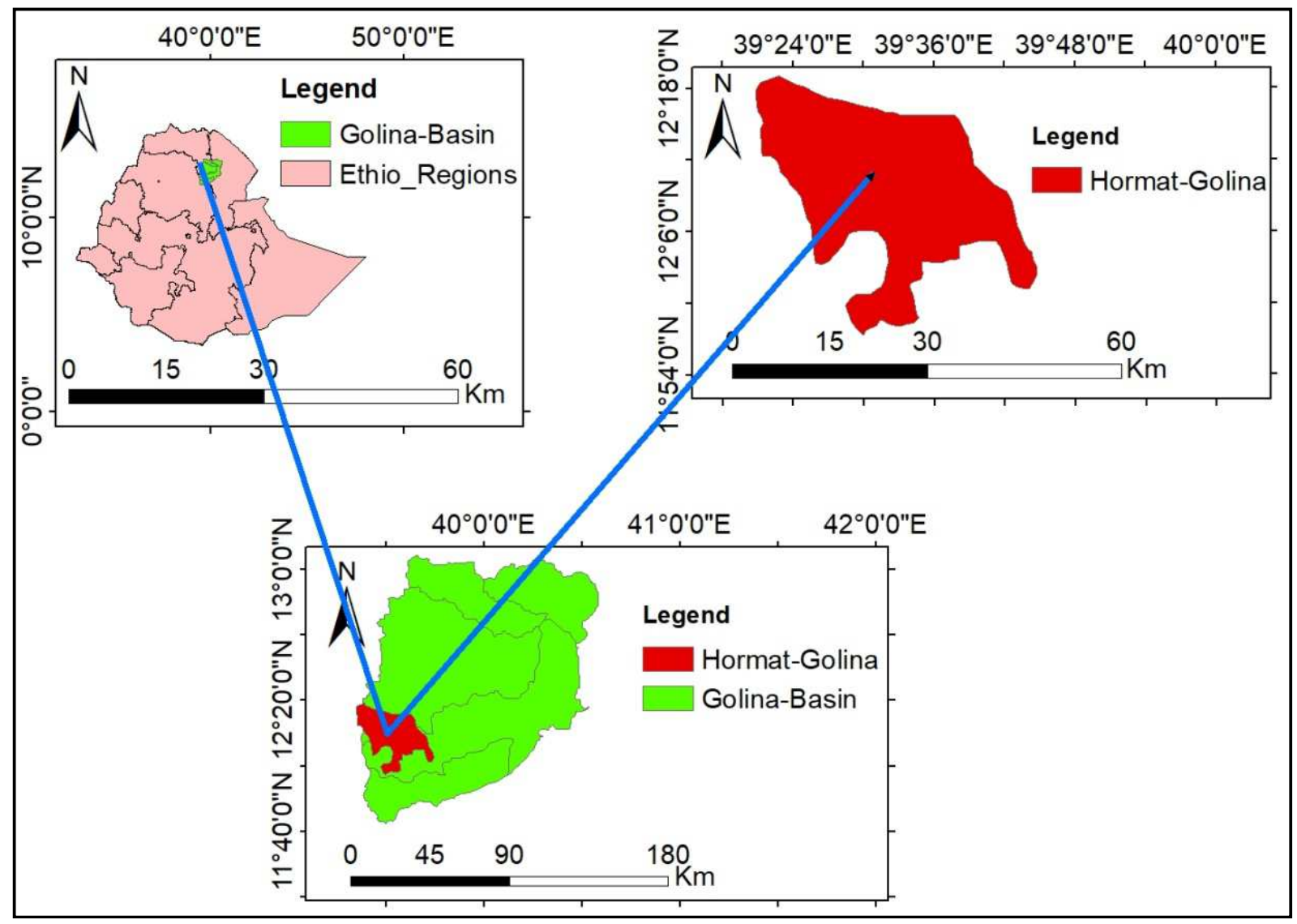

Figure 1. Location map of the study area.

The climate condition of Hormat-Golina Sub-basin is categorized as semi-arid and the temperature ranges from $12^{\circ} \mathrm{C}$ in December to $35^{\circ} \mathrm{C}$ in April, with a mean annual temperature of $23.1^{\circ} \mathrm{C}$. The mean annual rainfall of $724 \mathrm{~mm}$ and its distribution is highly influenced by orographic effect.

Based on field observation and Satellite image (USGS, Land sat image, 2019), the Sub-basin had Agricultural land, Forest Land, Urban area, water body and Bare land types of land use land cover units. Among those land use units' Agricultural land use units had the dominant land use land cover units while Water body land use land unit had small area coverage.

The study area has located near the highlands of Zobel Mountain from the Eastern direction and highlands in the North Western direction. From the previous Geological study which was carried out by Metaferia Consulting Engineers (MCE, 2009) and Geo-Engineering Service (GES, 2003) the main aquifer in the kobo-Girana valley had unconsolidated sediment.
The Northwestern highlands have originated from Basaltic rocks. The Eastern ridge (Zobel Mountain) originated from the Rhyolite and the valley floor originates from alluvial deposits.

The Sub-basin has 34 functional pumping wells and 8 observation wells (KGVDPO). For this analysis, irrigation boreholes and Kobo town water supply wells that tap on the alluvial aquifer were used. Not all boreholes are being used for the irrigation at present. Currently no continuous recorded groundwater data was available concerning how the groundwater has been utilized during irrigation period within the existing wells. The pumping time during irrigation seasons has been varied from 8 hours to 16 hours. The pumping and observation wells has densely populated in Western boundary of Hormat-Golina Sub-basin. The lithological characteristics of each well were initially assessed from Metaferia Consulting Engineers (MCE, 2009). The majority of water level measurements have taken from pumping wells without monitoring wells. 


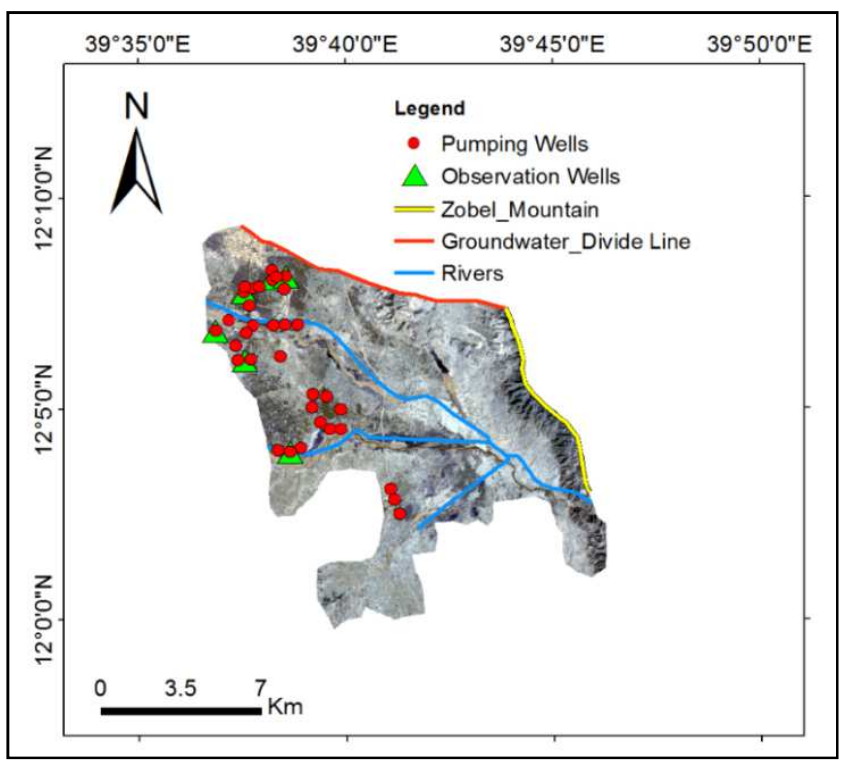

Figure 2. The location of pumping and observation wells.

\subsection{Data Collection and Analyses}

\section{(i) Groundwater Sampling}

In order to understand the effect of fertilizers on groundwater quality, groundwater samples were taken from pumping wells. Testing the whole pumping wells could provide best information about the physico-chemical characteristics of the groundwater. However, laboratory expenses were expensive to test water from all wells. Based on this limitation, this study tried to show the pattern of groundwater quality parameters (Nitrate, Phosphate and Chloride concentrations) from three supply wells. In this study, the three wells were selected based on frequency of applied fertilizers around the wells. One sample well was selected in the Eastern boundary of Hormat-Golina and the other two sample wells were selected from the Western boundary. The locations of the sampling wells (X and $\mathrm{Y}$ coordinates in UTM, respectively) are: Observation Well One $\left(\mathrm{OW}_{1}\right)$ : 569928 and 1341651; Observation Well Two $\left(\mathrm{OW}_{2}\right)$ : 568121 and 1337977; and Observation Well Three $\left(\mathrm{OW}_{3}\right)$ : 566854 and 1339266

\section{(ii) Laboratory Analyses}

In the laboratory, Nitrate concentration from Urea was determined by Phenoldisulphonic acid method, and for Phosphate concentration, residues were calculated by using Spectrophotometer. Chloride concentrations from the released wastes were determined by titration method. The groundwater samples were taken from the three observation wells on the basis of the site investigation where the farmers have been using excessive fertilizers. The analyses were carried out in Soil and Water Laboratory of Sirinka Agricultural Research Center.

\subsection{MT3D Model-based Groundwater Quality Analyses}

The MT3D Mass Transport Model was used for determining the concentration of Nitrate and Phosphate from applied Urea and DAP fertilizers within three-month prescribed time.

\subsubsection{Description of the MT3D Model}

MT3D is a modular three-dimensional transport model for the simulation of advection, dispersion, and chemical reactions of dissolved constituents in groundwater concentration.

MT3D has a comprehensive set of options and capabilities for simulating advection, dispersion, and chemical reactions of contaminants in groundwater flow systems under general hydrogeological conditions. The modular structure of the transport model makes it possible to simulate advection, dispersion, source mixing, and chemical reactions.

MT3DMS can be used to simulate changes in concentrations of contaminants in groundwater considering advection, dispersion, diffusion and some basic chemical reactions, with various types of boundary conditions and external sources. The chemical reactions included in the model were equilibrium-controlled with first-order reactions.

Linear equilibrium adsorption of a single dissolved species with uniform dispersion value was selected for this simulation in the entire model domain. The source of contamination was designated as a Recharge Concentration that serves as a source of contamination to infiltrating precipitation and surface irrigation. The transport simulation was added to the three observation wells to the model to monitor the concentrations from each chemical fertilizer at selected locations down-gradient of the area.

The measured total Porosity of void of materials was used by MT3D to determine the chemical reaction coefficients, and for calculating the average linear groundwater flow velocity in the particle tracking solution schemes.

The governing equation for Solute transport model through saturated porous media in three dimensions to simulate the migration of contaminant towards to groundwater storage is given in Equation 1.

$$
\left.\frac{\partial c}{\partial t}=\frac{\partial}{\partial x i}\left[D i j \frac{\partial}{\partial x i}\right]-\frac{\partial}{\partial x i}(V i c)+\frac{q s}{\theta} c s+\sum_{k=1}^{n} R k\right)
$$

where $\mathrm{C}$ is the concentration of contaminant dissolved in groundwater, $t$ is the time $(t), X_{i}$ is the distance along the respective Cartesian coordinate axis, $D_{i j}$ is the hydrodynamic dispersion coefficient, $V_{i}$ is the seepage or linear pore velocity, $\mathrm{q}_{\mathrm{s}}$ is the volumetric flux of water per unit volume of aquifer representing sources (positive) and sinks (negative), $\mathrm{C}_{\mathrm{s}}$ is the concentration of sources or sinks, $\theta$ is the porosity of the porous medium and, $R_{k}$ is the chemical reaction term.

\subsubsection{Model Discretization}

The conceptual model has used central finite difference method, which involves fitting the conceptual model to finite difference grids. This allows confirming the grid to each wells and boundary conditions. In Hormat-Golina Sub-basin, the numerical model has mapped with 40 rows and 40 columns with the corresponding cell height of 636.324 and $442.588 \mathrm{~m}$ along the $\mathrm{X}$ and $\mathrm{Y}$ direction respectively. Deformed grid type was selected for (the tops and bottoms of 
the model layers follow the horizons elevations).

\section{Results and Discussion}

\subsection{Laboratory Analyses-based Groundwater Quality Assessment}

The ground-water quality investigation in the selected supply wells were included laboratory analysis for nutrients.
The potential health effects of nitrate and phosphate are included to assist local communities in water-resource management issues specific to these chemicals.

The effect of fertilizer application on groundwater quality in case of Hormat-Golina Sub-basin was studied by analyzing water samples taken from the selected observation wells in various times. The results of the analyses are presented in Table 1.

Table 1. Laboratory results of Nitrate, Phosphate and Chloride concentrations.

\begin{tabular}{|c|c|c|c|c|c|c|c|}
\hline \multirow{2}{*}{ Well ID } & \multicolumn{2}{|c|}{ Coordinate (UTM) } & \multirow{2}{*}{ Depth (m) } & \multirow{2}{*}{ Observation date } & \multicolumn{3}{|c|}{ Concentration (mg/l) } \\
\hline & $\mathbf{X}$ & $\mathbf{Y}$ & & & Nitrate & Phosphate & Chloride \\
\hline \multirow{4}{*}{$\mathrm{OW}_{1}$} & \multirow{4}{*}{569928} & \multirow{4}{*}{1341651} & 21.2 & $1 / 17 / 2019$ & 5.6 & 0.42 & 8.37 \\
\hline & & & 20.7 & $2 / 16 / 2019$ & 7.0 & 0.44 & 8.77 \\
\hline & & & 20.5 & $3 / 18 / 2019$ & 7.2 & 0.49 & 9.75 \\
\hline & & & 20.4 & $4 / 17 / 2019$ & 8.4 & 0.52 & 10.86 \\
\hline \multirow{4}{*}{$\mathrm{OW}_{2}$} & \multirow{4}{*}{568121} & \multirow{4}{*}{1337977} & 19.1 & $1 / 17 / 2019$ & 8.4 & 0.53 & 11.23 \\
\hline & & & 18.7 & $2 / 16 / 2019$ & 9.8 & 0.54 & 11.82 \\
\hline & & & 18.4 & $3 / 18 / 2019$ & 11.3 & 0.69 & 13.26 \\
\hline & & & 18.3 & $4 / 17 / 2019$ & 14 & 0.72 & 16.87 \\
\hline \multirow{4}{*}{$\mathrm{OW}_{3}$} & \multirow{4}{*}{566854} & \multirow{4}{*}{1339266} & 28.3 & $1 / 17 / 2019$ & 2.8 & 0.31 & 6.63 \\
\hline & & & 28 & $2 / 16 / 2019$ & 4.2 & 0.37 & 6.75 \\
\hline & & & 27.8 & $3 / 18 / 2019$ & 4.2 & 0.41 & 7.79 \\
\hline & & & 27.6 & $4 / 17 / 2019$ & 4.7 & 0.42 & 8.28 \\
\hline
\end{tabular}

In general, it can be observed from the table that the concentration of Nitrate, Phosphate and Chloride increased from January to April 2019 in all of the considered observation wells.

The result of the analysis for $\mathrm{OW}_{3}$ shows that the Nitrate concentration varied from $2.8 \mathrm{mg} / \mathrm{L}$ to $4.7 \mathrm{mg} / \mathrm{L}$ in relatively deeper groundwater depth when compared to $\mathrm{OW}_{1}$ and $\mathrm{OW}_{2}$. It can be observed from Table 1 that the water table of $\mathrm{OW}_{2}$ is located at shallower depth from the surface of the ground and the Nitrate concentration determined for the various sampling dates ranged from $8.4 \mathrm{mg} / \mathrm{L}$ to $14.0 \mathrm{mg} / \mathrm{L}$. These results show that, in the study area, with shallow groundwater table depth, the amount of leached Nitrate that join the groundwater increases. This result is similar to the finding obtained by Eltarabily et al. (2017).

Similar to the Nirtate concentration, the concentration of Phosphate of the three observation wells increased with time as presented in Table 1. The laboratory analyses results of the samples taken at various dates showed that the Phosphate content of the groundwater varied from $0.31 \mathrm{mg} / \mathrm{L}$ to 0.42 $\mathrm{mg} / \mathrm{L}$ at a relatively deeper groundwater table level $\left(\mathrm{OW}_{3}\right)$. When the groundwater depth is relatively shallow, as in $\mathrm{OW}_{2}$ and $\mathrm{OW}_{1}$, the concentration of the leached Phosphate increased with decreasing depth of groundwater table.

As can be seen from Table 1, at the three observation wells the concentration of chloride was found to range from 6.6 to $16.8 \mathrm{mg} / \mathrm{l}$. The concentration of Chloride at the three observation wells showed similar trend with the concentration of Nitrate and Phosphate. The laboratory analyses-based results showed that the Chloride content of the groundwater at $\mathrm{OW}_{3}$ varied from $6.63 \mathrm{mg} / \mathrm{L}$ to $8.28 \mathrm{mg} / \mathrm{L}$. The water table at Observation well two (OW2) is located at shallower depth, and its Chloride concentration was found to varied from $11.23 \mathrm{mg} / \mathrm{L}$ to $16.87 \mathrm{mg} / \mathrm{L}$. These results show that, with decreasing groundwater table depth, the amount of Chloride concentration increases as also seen at $\mathrm{OW}_{1}$. In addition, the groundwater quality analysis results revealed that the highest concentration of chloride was found at Observation Well Two $\left(\mathrm{OW}_{2}\right)$. The areas with higher chloride concentration are identified as the most densely populated part of the Sub-basin contributing Chloride to the groundwater as a result of various anthropogenic activities. Studies on nutrient concentration in groundwater have been widely reported during recent decades in many parts of the world. The e ects of irrigation and fertilization could increase the nutrients in groundwater, salinization of the soil and groundwater below the fields [12]. High nutrient content in groundwater is usually related to excess fertilization of crop-lands. The major nutrients derived from agricultural activities are nitrate, phosphate and potassium. The nitrate molecule is highly mobile and plays a role in pollution resulting from agricultural activities [6, 8, 12]. Other nutrients applied to the cropland, such as phosphate and potassium, can also dissolve and move from the surface towards the water table through the vadose zone. The contribution of manmade activities to major ion composition in groundwater is limited in comparison to nutrients.

\subsection{Model-based Groundwater Quality Assessment Results}

Using mass transport model, the time serious of the concentration of every groundwater parameters could be shown in the graphical form. The model-based results of concentration of Nitrate, Phosphate and Chloride from the three observation wells are depicted in Figures 3, 4 and 5, respectively. As can be seen from the figures, the concentration of these parameters showed increasing trend. 


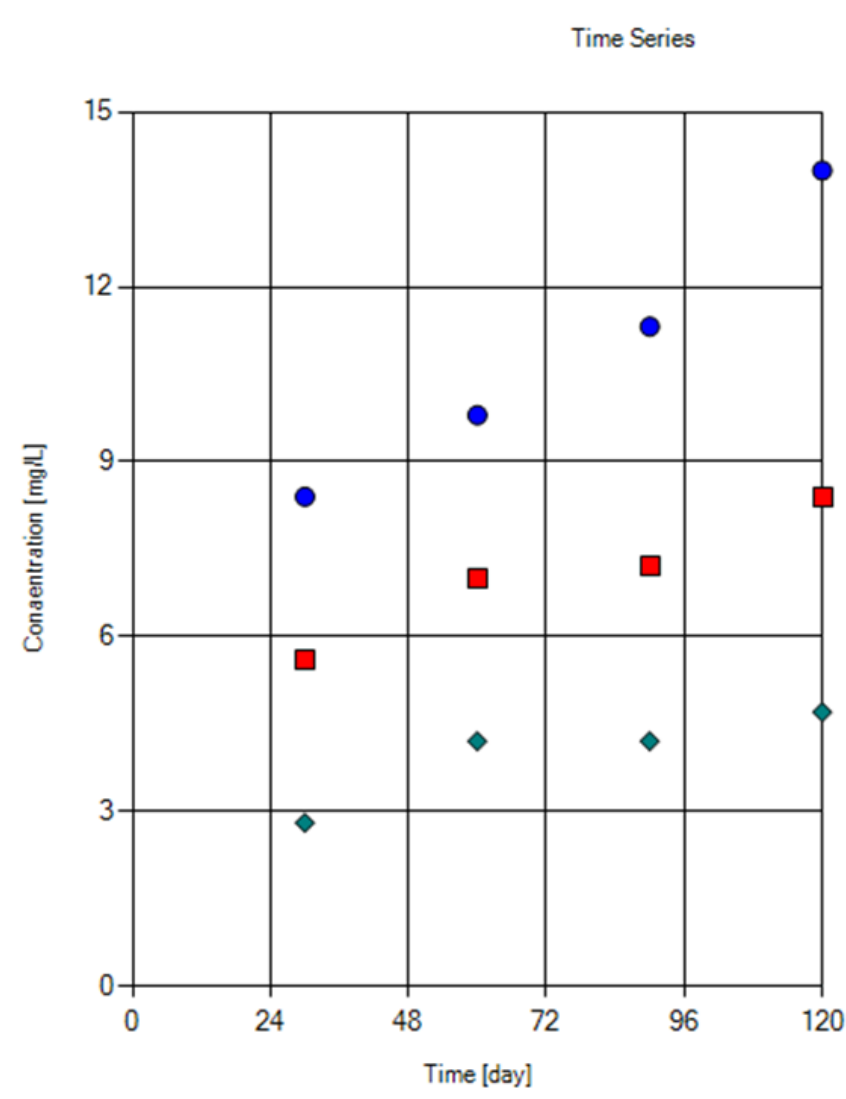

Legend

- Observation well 2

- Observation well 1

- Observation well 3

Figure 3. The concentration Nitrate in a time series.

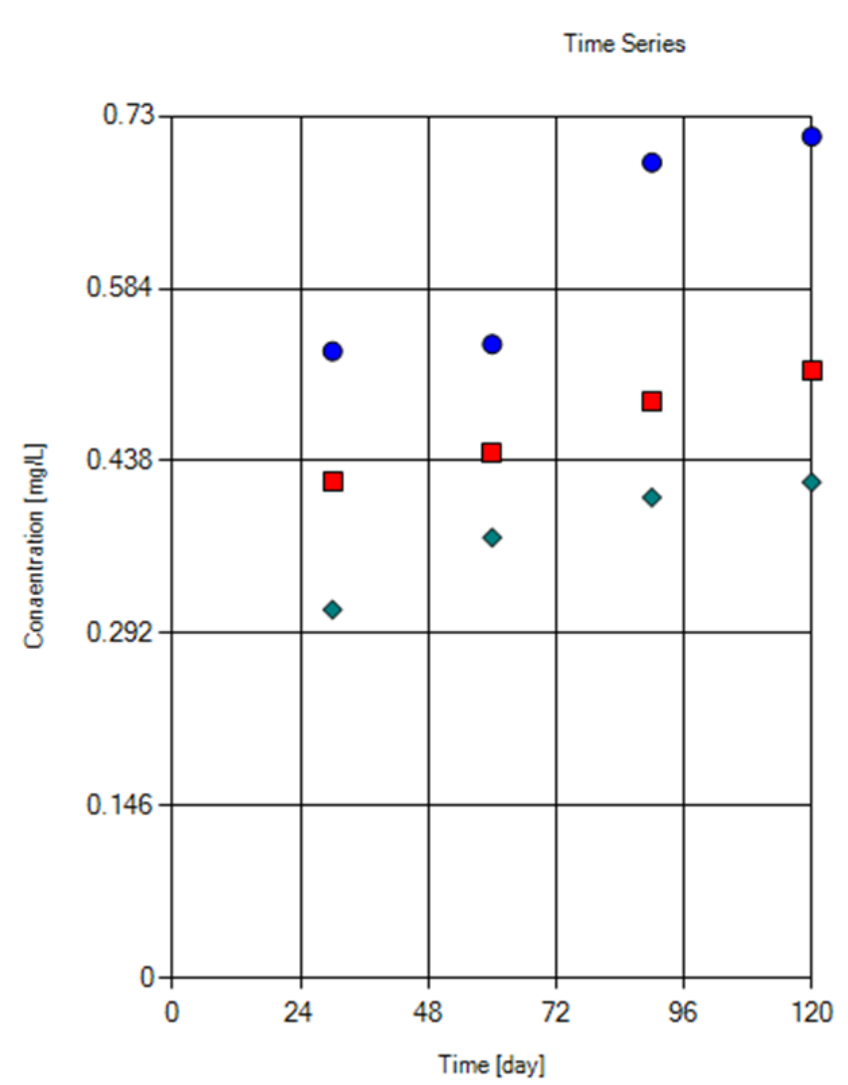

Legend

- Observation well 2

- Observation well 1

Observation well 3

Figure 4. The concentration of Phosphate in a time series. 


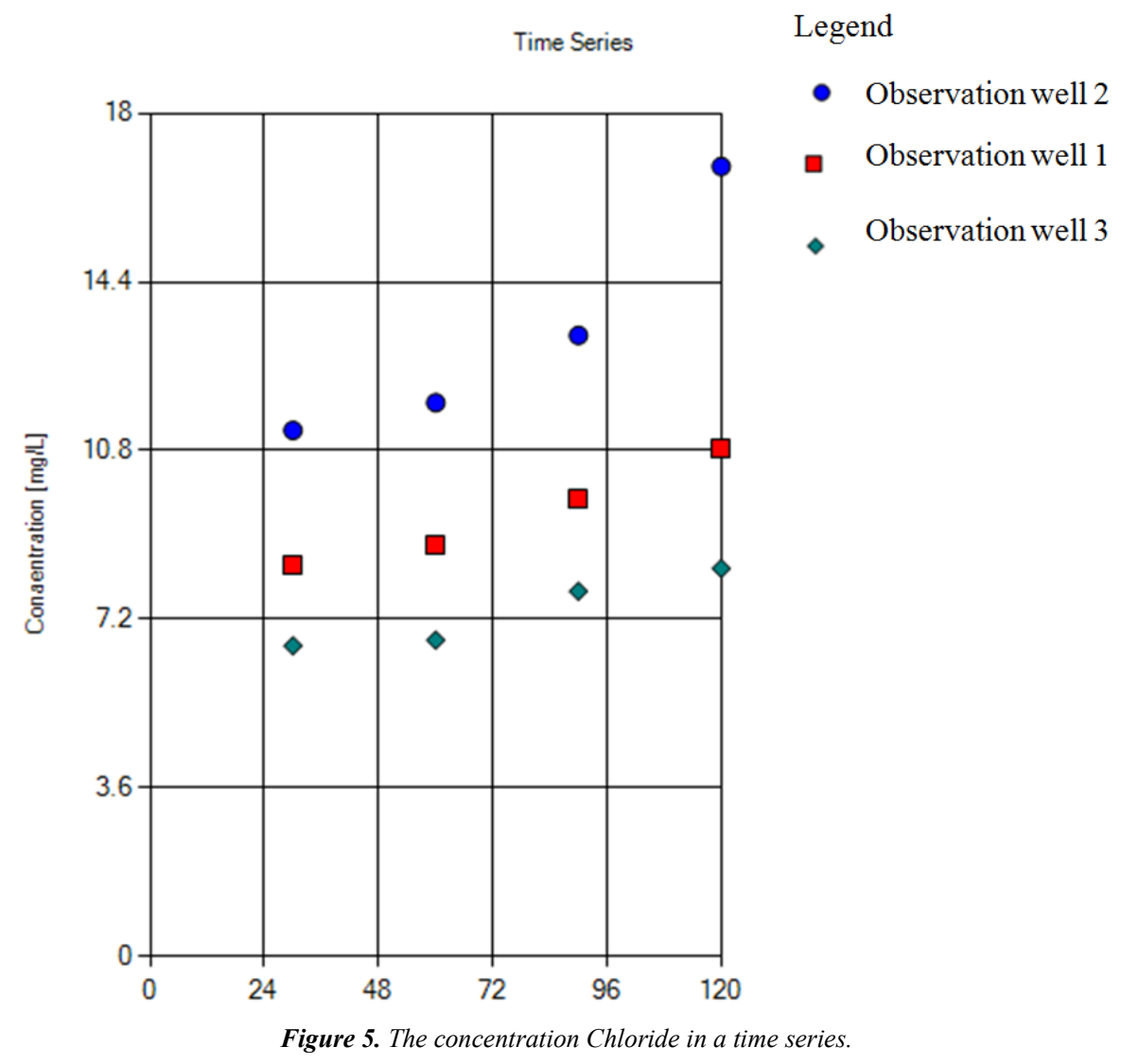

\subsection{Model Performance Results}

The performance of the model was evaluated using Standard Error of the Estimate (SEE), Root Mean Squared Error (RMSE), Normalized Root Mean Square (NRMS) and Coefficient of Determination $\left(\mathrm{R}^{2}\right)$ as performance indicators [1]. The values of these indicators are presented in Table 2.

Table 2. Values of model performance indicators.

\begin{tabular}{llll}
\hline Model status & Nitrate & Phosphate & Chloride \\
\hline SEE $(\mathrm{mg} / \mathrm{l})$ & 0.33 & 0.018 & 0.28 \\
RMSE $(\mathrm{mg} / \mathrm{l})$ & 1.1 & 0.056 & 1 \\
NRMS $(\%)$ & 12.93 & 14.65 & 15.08 \\
$\mathrm{R}^{2}$ & 0.94 & 0.87 & 0.94 \\
\hline
\end{tabular}

The Standard Error of the Estimate ( $S E E)$ is a measure of the variability of the residual around the expected residual value.

The Normalized Root Mean Squared is the RMS divided by the maximum difference in the observed head values.

The Correlation Coefficient $(R)$ is calculated as the covariance (Cov) between the calculated results and the observed results at selected data points divided by the product of their standard deviations.

\section{Conclusions}

Farmers are using excessive fertilizers (commonly Urea and DAP) which was the root cause of deteriorating groundwater quality in relation to Nitrate and phosphate concentration with a series of time.
The following conclusions have drawn from the results obtained from this study.

Farmers are using massive Urea and DAP fertilizers which were the root cause of deteriorating groundwater quality in relation to Nitrate and Phosphate concentration with series of time.

\section{References}

[1] Anderson, M and Wossener, W. W. 1992. Applied groundwater modeling simulation of flow and advective transport, Florida.

[2] Brouyere, S., Carabin, G. and Dassargues, A. 2004. Climate change impacts on groundwater resources: modeled deficits in a chalky aquifer, Geer basin, Belgium, Hydrogeology Journal, Volume. 12, P. 123-134.

[3] Chiang, W. H. 2005. 3D groundwater modeling with PMWIN: A Simulation system for modeling groundwater flow and transport processes. Second edition, ISBN-13978-3-54027590-9, Springer Berlin Heidelberg New York.

[4] Craig, C., Rick, E., Susan, H., Rafik, H., Gabrielle, P. and Carolina, P. 2010. Water and Climate Change: Impacts on groundwater resources and adaptation options. Water Working Notes are published by the Water Sector Board of the Sustainable Development Network of the World Bank Group. Note number, 25.

[5] Crosbie, R., McCallum, J., Walker, G. and Chiew, F. 2010. Modeling in climate change impacts on groundwater recharge in the Murray-Darling Basin, Australia. Hydrogeology Journal, Vol 18 No7, P. 1639-1656. 
[6] Divya, J. and Belagali, S. L. 2012. Impact of chemical fertilizers on water quality in selected agricultural areas of Mysore district, Karnataka, India. Department of Studies in Environmental Science, University of Mysore, India. International journal of environmental sciences volume 2, no 3, p. 1449-1457.

[7] Herrera, P. M. and Hiscock, K. 2008. The effects of climate change on potential groundwater recharge in Great Britain.

[8] Hogeboom, H. J. Pieter, R., Maarten, S. and Martijn, J. 2013. Modeling the Influence of Groundwater Abstractions on the Water Level of Lake Naivasha, Kenya Under DataScarce Conditions, University of Twente, Netherland. Department of Water Engineering \& Management (WEM). Volume 29 issue 12, P. 4447-4463.

[9] Kebede, S., Hailu, A., Crane, E. and Dochartaigh, B. E. 2018. Africa Groundwater and Hydrogeology of Ethiopia. British Geological Survey.

http://earthwise.bgs.ac.uk/index.php/Hydrogeology_of_Ethiop ia /Accessed on 06 December 2018/.
[10] Nata Tadesse, Dessie Nedaw, Kifle Woldearegay, Tesfamichael Gebreyohannes and Frank, V. S. 2015. Groundwater Management for Irrigation in the Raya and Kobo Valleys, Northern Ethiopia. International journal of earth science and engineering, June 2015, Vol 08, No 3 P. 3646.

[11] Semu Moges. 2012. Agricultural Use of Groundwater in Ethiopia: Assessment of Potential and Analysis of Economics, Policies, Constraints and Opportunities. Addis Ababa University, Ethiopia.

[12] Siebert, S., Burke, J., Faures, M., Frenken, K., Hoogeveen, J., Doll, P. and Portmann, F. 2010. Groundwater use for irrigation as a global inventory. Institute of Crop Science and Resource Conservation, University of Bonn, Bonn, Germany. Food and Agriculture Organization of the United Nations, Rome, Italy. Institute of Physical Geography, Goethe University Frankfurt, Frankfurt am Main, Germany. Hydrology and earth System Sciences. Volume 14, P. 1863-1880. 